\title{
Short Communication \\ Eagle Owl Bubo bubo and power line interactions in the Italian Alps
}

\author{
DIEGO RUBOLINI, ENRICO BASSI, GIUSEPPE BOGLIANI, \\ PAOLO GALEOTTI and ROBERTO GARAVAGLIA
}

\begin{abstract}
Summary
We reviewed the importance of power lines as a cause of mortality for Eagle Owl in the Italian Alps. Power lines were the most important cause of unnatural mortality for this species, accounting for over $50 \%$ of recorded casualties. The number of reported dead owls tended to be higher in September-October, suggesting an influence on juvenile dispersal. Furthermore, the significance of power lines as a cause of mortality increased over time, being lower in the 1960-1980 period than in 1981-1999. Electrocution, which usually takes place at medium-voltage $(15-30 \mathrm{kV})$ electricity poles, accounted for the vast majority of casualties. We suggest some protective measures that may be put into practice in the proximity of Eagle Owl breeding territories.
\end{abstract}

\section{Introduction}

Power lines have long been regarded as a relevant mortality factor for Eagle Owl Bubo bubo in Europe (Tucker and Heath 1994). This large owl, endangered and declining in several parts of its European distribution range (Tucker and Heath 1994), seems to be vulnerable to power lines, which have been deemed to be among the main factors affecting population decline in several areas (e.g. Germany, central Italy; Haas 1980, Penteriani 1996b). Birds die both from electrocution at mediumvoltage poles $(15-30 \mathrm{kV})$, used as hunting perches, and from collision with aerial high-voltage wires (Penteriani 1996a, 1998, Garavaglia and Rubolini 2000, Marchesi et al. 2001). Mortality due to power lines in Europe, compared with other known causes of mortality, ranges between $20 \%$ and $61 \%$ (mean $=38 \pm 17 \% \mathrm{SD}, n=$ 6 studies; Haller 1978, Olsson 1979, Mikkola 1983, Bezzel and Schöpf 1986, Larsen et al. 1987, Förstel 1990). Power lines may reduce population size in different ways, e.g. by affecting juvenile mortality (Marchesi et al. 2001), breeding pairs (widowing or death of parents), or post-juvenile dispersal.

\section{Methods}

We analysed the relevance of mortality due to power lines across the Italian Alps, where this species is widespread, with densities ranging between 1.0 and 3.9 pairs/100 $\mathrm{km}^{2}$ (Marchesi et al. 1999). Data were gathered from local bird reports (14\%, GPSO-Gruppo Piemontese Studi Ornitologici archives, data com- 
municated by G. Boano), published studies (24\%) and from unpublished information $(62 \%)$. Cited studies often do not specify methods of data acquisition, but presumably data were recorded in an opportunistic way, without any sampling design. However, data mostly refer to individuals occasionally reported by wildlife boards and private people, as there is no organized reporting system for bird casualties in Italy. No ringing recoveries were used in the analyses. Here we focus on the seasonal distribution of findings of Eagle Owls killed or injured at power lines, in order to identify which phase of the life cycle is mostly affected. The extent of the threat to Eagle Owls from power lines may have increased over time as a consequence of the increasing electrification in mountain areas (Larsen et al. 1987, Penteriani 1998). Thus we analysed a dataset of dead owls ( $n=53$ individuals) collected between 1960 and 1999 in one area of the central Alps (Province of Bergamo), to detect whether a long-term change existed in the relative weight of this cause of mortality. These data were recorded in an occasional way by local game wardens, so they should not contain any systematic recording bias. Finally, we evaluated the incidence of collision and electrocution, when the cause of death has been reported ( $n=69$ individuals). Although generally people fail to distinguish between wire strikes and electrocution accidents (e.g. Bevanger and Overskaug 1998) and the exact cause of death could not be verified directly in most cases, we are confident that specified causes were unbiased in this respect.

\section{Results and discussion}

Overall, we obtained information on 92 individual Eagle Owl mortalities. A review of the studies reporting causes of mortality in five regions of the Italian Alps showed that the average mortality due to power lines (both collision and electrocution) is $52 \pm 14 \% \mathrm{SD}$ ( $n=6$ studies and unpublished dataset, with observations mainly collected from 1980 onward, see Table 1 ). There was no significant difference among three sectors of the Alps (western, central, eastern; Table $1, \chi^{2}$ test for independence $=0.13, P=0.9$ ).

The assessment of the seasonal distribution of findings was based on a total of 67 casualties and injured individuals collected over the whole Alpine range (Figure 1). Corpses and injured birds were found throughout the year. Although there was no statistically significant seasonal variation in numbers of reported owls when data were grouped into 3-month intervals (August-October, Nov-

Table 1. Frequency (\%) of Eagle Owls found dead due to power lines in three sectors of the Italian Alps; $n$ refers to the total number of individuals for which cause of mortality was determined $(100 \%)$.

\begin{tabular}{lccr}
\hline Area & Frequency (\%) & $n$ & References \\
\hline Western Alps & $54 \cdot 3$ & 35 & $\mathrm{a}, \mathrm{b}$ \\
Central Alps & 50.0 & $38^{\mathrm{a}}$ & This study \\
Eastern Alps & 52.3 & 146 & $\mathrm{c}, \mathrm{d}, \mathrm{e}$ \\
\hline
\end{tabular}

a Only data from 1981 onward.

References: a, Ruggieri et al. 1996; b, G. Boano, GPSO and R. Bionda, pers. comm.; c, Tormen and Cibien (1993); d, Sascor and Maistri (1996); e, Garavaglia and Rubolini (2000). 


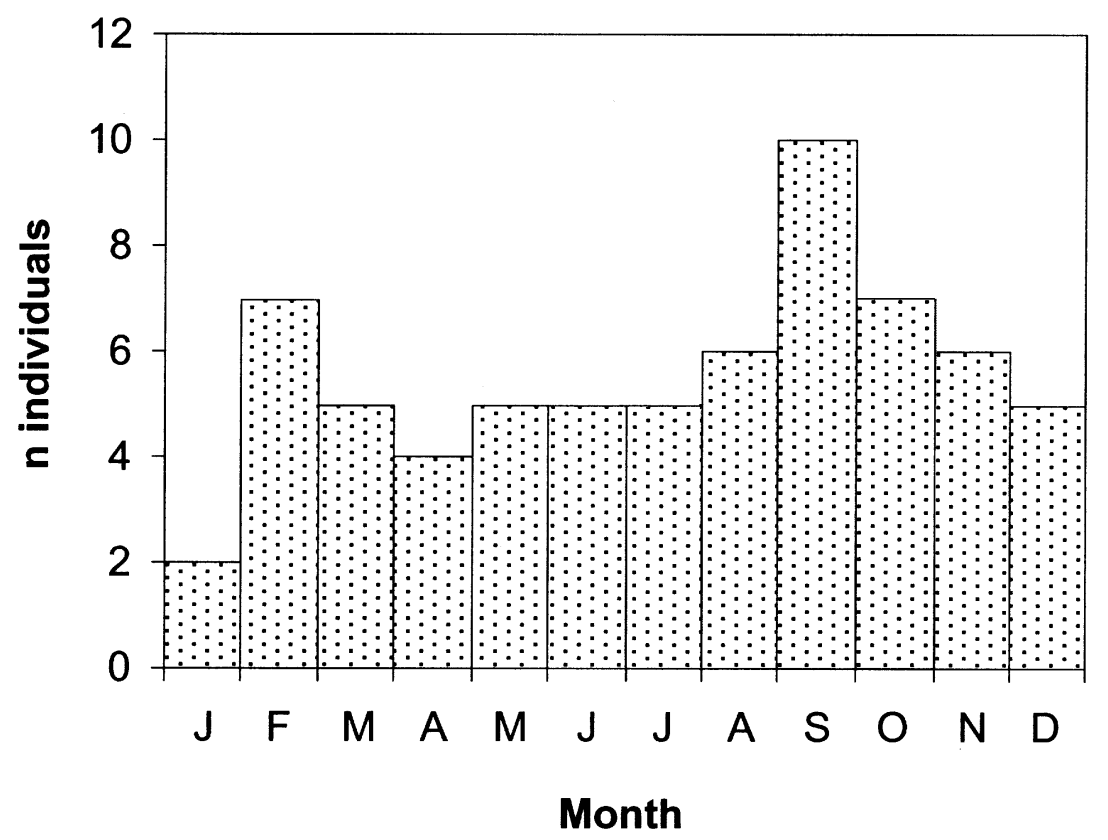

Figure 1. Monthly distribution of Eagle Owls found dead or wounded due to power lines in the Italian Alps ( $n=67$ individuals).

ember-January, February-April, May-July; $\chi^{2}=3.38, P=0.3$ ), deaths peaked during autumn (September-October). Although the age of dead owls was not recorded, this peak coincides with the timing of juvenile dispersal (Blondel and Badan 1986). Another less marked peak of dead birds was recorded in late winter-early spring (February), during the courtship period. Thus power lines may also affect potential breeders during territory establishment.

The relative significance of power lines as a cause of mortality for Eagle Owls in the Central Alps increased from $13.3 \%$ in 1960-1980 (overall $n=15$ ) to $50.0 \%$ in 1981-1999 (overall $n=38$; Fisher Exact test, $P=0.027$ ). This may be explained by a reduction in direct persecution (e.g. through accidental hunting and deliberate poaching; Fasce 1993) and an increasing electrification and urbanization of mountain areas (Larsen et al. 1987, Penteriani 1998). It may also be related to an increase and/or range expansion of the population breeding in this area, but unfortunately no reliable long-term population trends are available for the Italian Alps. An analysis of long-term population dynamics for the Swiss Alps indicates that, despite a conspicuous range expansion, numbers remained fairly stable or only slightly increased from the 1970s to the 1990s in regions bordering the Italian Alps (e.g. Canton Ticino and Canton Grigioni; Mosimann and Haller 1999). Whatever the reason for the observed increase in power line casualties, our data indicate that power lines are currently the most relevant cause of unnatural mortality for Eagle Owls.

Populations of this species in the Italian Alps do not seem to be threatened at present (Marchesi et al. 1999). Should a population decline occur due to any other reason (e.g. disturbance, loss of habitat, decrease of prey abundance; Fasce 1993), 
power lines may speed up this process, eventually leading to extinction of local populations and isolation of reproductive pairs. In the Appennines (central Italy), where Eagle Owls occur at much lower densities, power lines are considered among the main causes of local extinction and were shown to affect negatively the probability of recolonization (Penteriani and Pinchera 1990, Penteriani 1996b). Electrocution accounted for the majority of reported casualties $(85.5 \%)$, while collision accounted for the remaining $14.5 \%(n=69$, binomial test, $P<0.0001)$.

Although no specific information was available on the typology of dangerous power lines, electrocution generally takes place at medium-voltage electricity poles (Bevanger 1998, Janss and Ferrer 1999, Janss 2000). However, under particular environmental conditions, birds may be electrocuted at high-voltage poles (K. Bevanger pers. comm., Penteriani 1998). Consequently, it is highly recommended that the most dangerous medium-voltage poles (e.g. pin-type insulators on a grounded crossarm, a widespread assembly among Italian lines, Garavaglia and Rubolini 2000) be replaced, or otherwise modified (e.g. by installing an insulating cap on pin-type insulators). Alternatively, conductors could be insulated or buried in those areas where territorial pairs of Eagle Owls are known to occur. Mitigating actions may be unnecessary along the whole length of a power line, but should be focused along those sections crossing owl territories. Electrocution of Eagle Owls may also take place due to its large wing-span $(140-170 \mathrm{~cm})$ where simultaneous contact with two energized wires is possible (the distance between two phase conductors is less than $150 \mathrm{~cm}$ in typical Italian medium-voltage lines; Garavaglia and Rubolini 2000). Accordingly, replacement with insulated aerial cables (or buried cable) may be the ultimate solution to avian electrocutions in mountain areas. Although rather expensive (it requires an increased number of supporting poles), replacement with insulated aerial cable is at present a preferred option by Italian utilities, not purely for solving bird-related outages but mainly for other maintenance and service-related reasons. Most Italian lowvoltage lines are either insulated or buried (50\% insulated, $28 \%$ buried), while $33 \%$ of medium-voltage lines are insulated and less than $5 \%$ buried (Garavaglia and Rubolini 2000). In Scandinavia, pole-mounted transformers seem to be the most dangerous assembly to the Eagle Owl, and programmes have been running for their replacement by means of similar devices locked up on the ground (e.g. Størkersen 1992, cited in Bevanger 1994, K. Bevanger pers. comm.). It should be stressed that mitigating actions should also be set along the potential corridors used by dispersing juvenile owls (e.g. along Alpine valleys and rivers, Larsen et al. 1987, Ruggieri et al. 1996).

\section{Acknowledgments}

We acknowledge G. Moroni, W. Serpellini and L. Ziboni (Province of Bergamo), M. Ferloni (Province of Sondrio), S. Verri (Province of Udine), A. Gariboldi and L. Cattini (LIPU Parma), G. Boano (GPSO) and R. Bionda for their help. The Italian Ministry for Industry and Trade provided financial support to this research (D.M. MICA 26-01-2000). We thank K. Bevanger, one anonymous reviewer, and the Editor for useful comments and suggestions. O. Janni kindly checked the English version of the manuscript. 


\section{References}

Bevanger K. (1994) Bird interactions with utility structures: collision and electrocution, causes and mitigating measures. Ibis 136: 412-425.

Bevanger K. (1998) Biological and conservation aspects of bird mortality caused by electricity power lines: a review. Biol. Conserv. 86: 67-76.

Bevanger K. and Overskaug K. (1998) Utility structures as a mortality factor for raptors and owls in Norway. Pp. 381-391 in: R. D. Chancellor, B.-U. Meyburg and J. J. Ferrero eds. Holarctic birds of prey. Badajoz: ADENEX-WWGBP.

Bezzel E. and Schöpf. H. (1986) Anmerkungen zur Bestandsentwicklung des Uhus (Bubo bubo) in Bayern. J. Orn. 127: 217-228.

Blondel J. and Badan O. (1976) La biologie di Hibou Grand-duc en Provence. Nos Oiseaux 33: 189-219.

Fasce P. (1993) Gufo reale Bubo bubo. P. 146 in: E. Meschini and S. Frugis eds. Atlante degli uccelli nidificanti in Italia. Suppl. Ric. Biol. Selvaggina XX. Ozzano: Istituto Nazionale per la Fauna Selvatica.

Förstel A. (1990) Beobachtungen am Uhu Bubo bubo L. im Gehege, Zucht und Auswilderung in Nordbayern. Anz. orn. Ges. Bayern 29: 1-22.

Garavaglia R. and Rubolini D. (2000) Rapporto "Ricerca di Sistema" - Progetto BIODIVERSA - L'impatto delle linee elettriche sull'avifauna. Milan: CESI-AMBo4/oo5, CESI.

Haas D. (1980) Gefährdung unserer Großvögel durch Stromschlag: eine Dokumentation. Ökol. Vögel (Ecol. Birds) 2 (Sonderheft): 7-57.

Haller H. (1978) Zur Populationsökologie des Uhus Bubo bubo im Hochgebirge: Bestand, Bestandsentwicklung und Lebensraum in den Rätischen Alpen. Orn. Beob. 75: 237-265.

Janss G.F.E. (2000) Avian mortality from power lines: a morphologic approach of a species-specific mortality. Biol. Conserv. 95: 353-359.

Janss G.F.E. and Ferrer M. (1999) Birds and power lines. Collision, electrocution and breeding. Madrid: Quercus.

Larsen R.S., Sonerud G.A. and Stensrud O.H. (1987) Dispersal and mortality of juvenile eagle owls released from captivity as revealed by radio-telemetry. Pp. 215-219 in: R.W. Nero, R.J. Clark, R.J. Knapton and P.H. Hamre eds. Biology and conservation of northern forest owls. Symposium proceedings. Manitoba: USDA Forest Service.

Marchesi L., Pedrini P. and Galeotti P. (1999) Densità e dispersione territoriale del Gufo reale (Bubo bubo) in provincia di Trento (Alpi centro-orientali). Avocetta 23: 19-23.

Marchesi L., Pedrini P., Sergio F. and Garavaglia R. (2001) Impatto delle linee elettriche su una popolazione di Gufo reale Bubo bubo. Avocetta 25: 130.

Mikkola H. (1983) Owls of Europe. Calton: Poyser.

Mosimann P. and Haller H. (1999) Uhu/Grand-duc d'Europe Bubo bubo. Pp. 278-279 in: H. Schmid, R. Luder, B. Naef-Daenzer, R. Graf and N. Zbinden eds. Atlas des Oiseaux Nicheurs de Suisse/Verbreitungsatlas der Brutvogel der Schweiz. Sempach: Schweizerische Vogelwarte.

Olsson V. (1979) Studies on a population of eagle owl, Bubo bubo (L) in Southeast Sweden. Viltreoy 11: 1-99.

Penteriani V. (1996a) Il Gufo reale. Bologna: Edagricole.

Penteriani V. (1996b) La mortalité et le déclin du Hibou Grand-duc causés par le reseau électrique moyenne-tension dans la region des Abruzzes (Italie). P. 432 in: J.L. Mériaux and J. Trouvilliez eds. Lignes électriques et environnement. Actes du Colloque International. Metz: IEE and AMBE.

Penteriani V. (1998) L'impatto delle linee elettriche sull'avifauna. Rome: WWF Italia Serie Scientifica No. 4 .

Penteriani V. and Pinchera F. (1990) Declino del Gufo reale, Bubo bubo, in tre aree montane dell'Appennino abruzzese dal 1960 al 1989. Suppl. Ric. Biol. Selvaggina XVII: 351-356. 
Ruggieri L., Manfredo I. and Blondin M. (1996) The importance of electrical lines as a cause of mortality of the Eagle Owl (Bubo bubo) in the North-western Alps (Val d'Aosta, Italy). Pp. 8-9 in: M. Pandolfi ed. Abstracts of the $2^{\text {nd }}$ International Conference on Raptors. Raptor Research Foundation, University of Urbino.

Sascor R. and Maistri R. (1996) Il Gufo reale. Ecologia, status e dinamica di popolazione in Alto Adige. Trento: WWF-CEA.

Tormen G. and Cibien A. (1993) Il Gufo reale Bubo bubo in provincia di Belluno. Dati preliminari. Atti $I^{\circ}$ Convegno Faunisti Veneti, Montebelluna (TV): 53-59.

Tucker G.M. and Heath M.F. (1994) Birds in Europe. Their conservation status. Cambridge, U.K.: BirdLife International.

DIEGO RUBOLINI ${ }^{1}$, ENRICO BASSI, GIUSEPPE BOGLIANI and PAOLO GALEOTTI Laboratorio di Eco-Etologia, Dipartimento di Biologia Animale, Università di Pavia, p.zza Botta 9, I-2710o Pavia, Italy

${ }^{1}$ Author for correspondence; current address: Via Vespri Siciliani 5, I-20146 Milano, Italy. Email: rubolini@mail.inet.it

\section{ROBERTO GARAVAGLIA}

CESI, Centro Elettrotecnico Sperimentale Italiano G. Motta, via Rubattino 54, I-20134 Milan, Italy

Received 4 June 2001; revision accepted 18 September 2001 